\title{
Clinical Mastitis Gives Off-Flavor and Reduces Quality of Milk in Smallholder Goat Farms
}

\author{
J.O. Ondiek ${ }^{*}$ P.B. Ogore and F. Kemboi \\ Egerton University, Department of Animal Science, P.O. Box 536-20115, Egerton, Kenya \\ *Corresponding author
}

\section{Keywords}

Acid degree value,

Caprine, Free fatty

acid, Milk quality,

Pathogens, Somatic

cell counts,

Subclinical mastitis

\section{Article Info}

Accepted:

16 December 2017

Available Online:

10 January 2018

\section{A B S T R A C T}

\section{Introduction}

The dairy production in Kenya is a dynamic subsector in the livestock industry that is contributing one third of the National agricultural Gross domestic Product (GDP) (CBS, 2002). The industry is, however, dominated by smallholder farmers who mainly keep cows estimated to contribute between $60 \%$ and $90 \%$ of the total milk (Omore et al., 1999). In the last decade, dairy goats have gained popularity due to increased demand of goat milk and declining feed resources in smallholder farms (Ndegwa et al., 2000).
Inadequate feeds can be ameliorated by adoption of the abundant locally available multipurpose trees and shrubs (Ondiek et al., 1999; Ondiek et al., 2000).

Prevalence of mastitis infections and other livestock diseases (Omore 1997; Oliver 2009, Barlow 2011, Ondiek et al., 2013) is a common occurrence in dairy farming. Mastitis remains the most persistent and widely spread disease condition with economic concerns in smallholder dairy farms worldwide (Schalm et al., 1971; Barlow, 2011) but this can be ameliorated if organic animal production is practiced (Silva et al., 2014). In cases of 
mastitis infection, somatic cell counts (SCC) is a useful predictor of subclinical mastitis and therefore, an important parameter in evaluating milk quality and udder health. Elevated milk SCC is associated with altered protein quality, change in fatty acid composition, lactose, ion and mineral concentration, increased enzymatic activity and $\mathrm{pH}$ of raw milk (Coulon et al., 2003). Various studies have demonstrated that subclinical mastitis is a prevalent disease in smallholder dairy herds in Kenya (Omore 1997; Shitandi et al., 2004). Previous studies have shown the epidemiology, diagnosis and control (Omore, 1997); impacts on public safety (Shitandi and Sternesjo, 2001), the mastitis risk factors (Omore et al., 1999; Shitandi and Gathoni, 2004) but the impact of subclinical mastitis on raw milk composition and quality have yet to be comprehensively studied in dairy goat flocks.

It is hypothesized that the very high background SCC levels may have a negative impact on the composition and quality of raw milk produced in addition to reducing yield by up to $15 \%$ (Gelasakis et al., 2016). This study, as a part of a wider programme on mastitis dynamics and milk quality in caprines, aimed at evaluating the prevalence of mastitis infection, lactation stage and parity, quarter SCC levels and raw milk compositional quality in smallholder dairy goats. The objective of the study was to determine the effects of somatic cell count on the concentration of free fatty acids and $\mathrm{pH}$ in mastitic milk and establish its effects on the sensory quality of caprine milk.

\section{Materials and Methods}

\section{Animal selection}

This cross sectional study was conducted between February and April 2017 in Njoro smallholder farms with dairy goats under the
Community dairy goat programme who received 68 in-kid goats. During the study, farm selection was based on flock size (minimum of 5 goats), availability of lactating goats (minimum of 5) and the willingness of the farmer to participate. The dairy goat farmers were in groups formerly registered with the Ministry of Social Services, and therefore, benefitted from the programme. From the flocks that met the required selection criteria, a total of 15 farms in five villages, namely Tengecha, Njokerio, Mwigiti, Iriithia and Ngondu that received goats were selected and thereafter 20 goats were randomly sampled with four goats per village. Only clinically healthy animals were included in the study. All goats were in early to mid-lactation at sampling the study flock was screened for mastitis using a combination of CMT kit, udder palpation and visual examination of milk for abnormalities.

\section{Sampling}

The order of sampling was randomized in each of three sampling sessions. The sampling period was 3 weeks in which, 3 replications were done for the on- station flock in the University Farm, while 3 replications were done for the on-farm community flocks. Thus 6 replicates were obtained for the study. Halve milk samples were collected, after discarding the first three squirts of fore milk, while the goats were restrained in a standing position. The udders and teats were cleaned with warm water, dried and wiped thoroughly with cotton swabs soaked in $70 \%$ alcohol. From each teat, $5 \mathrm{ml}$ milk samples were aseptically collected in sterile sampling tubes for the bacteriological culture. Another aliquot was collected in $100 \mathrm{ml}$ bottles and refrigerated at $4^{\circ} \mathrm{C}$ for SCC and chemical analyses. The samples were transported to the chemical and microbiological laboratory in an ice box and tested within 6 hours of collection.

Bacteriological analysis 


\section{Blood agar culturing}

Using sterile disposable loops, $1 \mathrm{ml}$ of milk was streaked on half plate of blood agar (Becton Dickinson and Company, USA) supplemented with 5\% ovine blood and incubated aerobically at $37^{\circ} \mathrm{C}$. The plates were examined for bacterial growth at 24hours and 48hours. Pure cultures were further examined for morphological, staining, cultural characteristics and biochemical reactions. Cases with no growth were re-incubated at $37^{\circ} \mathrm{C}$ for another 24hours, while for mixed growth, a new halve was re-examined. Bacteria were identified using standardized procedures (Nancy et al., 1999). The quarters were identified as not infected (NI) if no organisms were isolated, or infected with major pathogens (MAP) if other Streptococci species, e.g. S. aureus and Escherichia coli were isolated.

\section{Total viable counts}

The pour plate method as described by Shearer and Harris (2005) was used. Serial dilutions of the samples were made using distilled water to $10^{-5}$. Then $0.05 \mathrm{ml}$ dilutions $103-10^{-5}$ were used to inoculate molten agar at $45^{\circ} \mathrm{C}$. The inoculated medium was poured into sterile petri dishes. Allowed to cool and incubated at $37^{\circ} \mathrm{C}$ for 48 hours. The colonies were counted and the number multiplied by the corresponding dilution factors.

\section{Coagulase test}

A slide was marked into two sections with a marker pen after a loopful of sterile saline water $(0.85 \% \mathrm{NaCl})$ was placed on each section and emulsified with a loopful of streak colonies from a 18-24hour blood agar till a homogeneous suspension was obtained. A drop of rabbit plasma was added to each slide preparation. The set up was stirred for 5 seconds and then carefully observed for clumping. The results were reported as either infected with major pathogens (MAP) or as not infected (NI).

\section{Coagulase test}

A loopful of a 24hour blood agar culture was emulsified with a loopful of $110 \%$ hydrogen peroxide on a slide and carefully examined and observed for effervescence. Slides that showed effervescence were reported as positive cultures.

\section{Somatic cell counts (SCC)}

The SCC was determined by direct microscopic somatic cell count (DMSCC) method as stipulated by US FDA/CFSAN (2005). The single Strip factor (SSF) was used for SCC enumeration. Before analysis, the microscope (Reicheert Neovar 295A) with $1.8 \mathrm{~mm}$ oil emulsion objective binocular lens condenser with iris diaphragm and x10 wide field oculars was calibrated to calculate the single strip factor. This was done using a stage micrometer to measure the field diameter (D) of the oil emulsion objective lens in $\mathrm{mm}$ and the SSF was calculated as: $\mathrm{SSF}=10000 /(11.28$ $\mathrm{x}$ D).

The Lovewitz-Weber stain, prepared by combining $0.5 \mathrm{~g}$ certified methylene blue chloride, $56 \mathrm{ml}$ 95\% ethyl alcohol, $40 \mathrm{ml}$ xylene and $4 \mathrm{ml}$ glacial acetic acid, was used for staining. Somatic cell count for each milk sample was determined by spreading $10 \mu 1$ of thoroughly mixed milk from each sample $1 \mathrm{~cm}^{2}$ area on the glass slide. The slides were left to air dry followed by staining with the Lovewitz-Weber stain. The excess stain was drained off and the slides air dried and rinsed in 3 changes of flowing tap water before examining the smears under oil objective lens. The SCC was counted across the smear to cover a diameter (single strip) of $1 \mathrm{~cm}^{2}$ area on 
the glass slide. The SCC was counted as follows:

$\mathrm{SCC} / \mathrm{ml}=\mathrm{n}_{\mathrm{SSF}} \times \mathrm{SSF}$, where;

$\mathrm{SCC} / \mathrm{ml}=$ the somatic cell count per $\mathrm{ml}$ of milk,

$\mathrm{n}_{\mathrm{SSF}}=$ number of cells counted in a single strip (diameter) and

$\mathrm{SSF}=$ the single strip factor

\section{Chemical analysis}

\section{Acid degree value (Free fatty acid)}

The free fatty acid (FFA) content of each sample (expressed as micro equivalent $/ \mathrm{ml}$ of milk) was determined by the modified Dole extraction method. Each 2-5ml of milk sample was mixed with $10 \mathrm{ml}$ of extraction mixture (Isopropanol: petroleum: ether. $4 \mathrm{~N}: \mathrm{H}_{2} \mathrm{SO}_{4}$ : 40:10:1) in a $35 \mathrm{ml}$ test tube followed by addition of $6 \mathrm{ml}$ of distilled water, shaking the stoppered test tube vigorously for 15 minutes.

The two layers formed were allowed to settle for 5 and 10 minutes and the supernatant was withdrawn and transferred to a $50 \mathrm{ml}$ conical flask. Six (6) drops of $1 \%$ methanoic phenolphthalein indicator was added into the solution after which the solutions were titrated with $0.02 \mathrm{~N}$ methanoic potassium hydroxide (frequently standardized against standard potassium acid phthalate). Blanks, in which milk was replaced with distilled water, were used to obtain background titration. The FFA content was used as an index of lipolysis in the milk samples. The FFA was calculated as shown:

$\mathrm{FA}(\mu \mathrm{eq} / \mathrm{ml})=\left(10^{3} \times \mathrm{T} \times \mathrm{N}\right) /(\mathrm{P} \times \mathrm{V})$ where:

$\mathrm{T}=$ net titration volume, $\mathrm{P}=$ proportion of upper layer titration (vol. Of withdrawn / total vol. of supernatant),

$\mathrm{V}=$ volume in $\mathrm{ml}$. of milk.

The FFA values were converted to the corresponding acid degree value (ADV) based on oleic acid according to Corks and van Rede (1966) using the following conversion formula:

$\mathrm{ADV}=1.99 \times \% \mathrm{FFA}$ (as oleic acid).

\section{Milk pH and sensory evaluation}

The $\mathrm{pH}$ of each sample was measured using the potentiometric method immediately upon arrival in the laboratory. The influence of SCC on sensory characteristics of the milk samples were measured using 10 tasters who were trained as sensory panellists, to score and give their level of affection based on the Hedonic Scoring scale of 1-5 $(1=$ dislike extremely, to $5=$ like extremely) of milk at different levels of SCC. The milk samples were batch pasteurized to ensure safety of the product. The panellists were instructed to be as consistent as possible in their affective ratings throughout the study. The criteria for sensory evaluation and the accompanying explanation were presented to the sensory panellists during each session together with the evaluation form to minimize uncertainty regarding the meaning of the values allocated. The milk samples were presented to each panellist in a closed environment to prevent light oxidation and to be tasted at approximately $20^{\circ} \mathrm{C}$.

\section{Results and Discussion}

\section{Isolated pathogens}

Milk contains microorganisms that are useful like lactobacillus spp. However, mastitis causing microorganisms are reported by White and Hinckley (1999) and Bergonier et al., (2003) and the more prevalent are 
Staphylococcus spp., $\quad 38.2 \% \quad(n=406)$; Staphylococcus aureus, $11.0 \%(n=117)$ and to a lesser extent Streptococcus spp., 4.1\% (n $=43$ ) and Streptococcus agalactiae, Escherichia coli, $1.6 \% \quad(n=17) \quad$ and Pseudomonas spp., $1.2 \%(n=13)$. They report that culture-negative mastitis which contained $>1 \times 10^{6} \mathrm{SCC} / \mathrm{ml}$ resulted in $43.9 \% \quad(n=466)$ mastitic milk, showing that high SCC does not indicate mastitis infection. In the current study, only Staphylococcus aureus (38.6\%) and Escherichia coli (22.9\%) were isolated, mainly due to poor milking hygiene (Murphy et al., 2007; Persson and Olofsson, 2011; Gelasakis et al., 2016) and these findings corroborate with the current study.

\section{Free fatty acids}

The descriptive statistics for FFA are presented in Table 1. The mean value of FFA (expressed as acid degree value) obtained was $3.76 \pm\left(7.95 \times 10^{-1}\right) \mu \mathrm{eq} / \mathrm{ml}$ significant at $\mathrm{p}=0.05$. The highest value obtained was 6.567 $\mu \mathrm{eq} / \mathrm{ml}$, which is far beyond the $1.0 \mu \mathrm{eq} / \mathrm{ml}$ recommended by DPC (1991) who recommended that samples from individual farms should have ADVs of less than 0.80 $\mu \mathrm{eq} / \mathrm{ml}$ and that when results exceed 1.00 $\mu \mathrm{eq} / \mathrm{ml}$, the milk develops a soapy -bitter taste. For ADV results exceeding $1.2 \mu \mathrm{eq} / \mathrm{ml}$, one can expect consumer complaints and a negative effect on consumption and sales of such milk. Action should be taken when samples have a result above $1.00 \mu \mathrm{eq} / \mathrm{ml}$.

The acid degree value is an indicator of the potential for rancid flavor in milk. It is an estimate of the level of free fatty acids (FFA) which occur as a result of the enzymatic (lipase) breakdown of butter fat. High levels of certain FFAs in milk result in a rancid flavor in milk. Acid degree values (ADV) of greater than $1.0 \mu \mathrm{eq}$ might be perceived as rancid according to DPC (1991) As the ADV exceeds $1.4 \mu \mathrm{eq}$, the flavor criticism may range from "lacks freshness" to "rancid or unclear" taste, depending on the individual tasters. Most causes of high ADVs occur due to excessive milk agitation. Pasteurization inactivates most natural lipases in milk, thus minimizes the development of rancidity, though ADCs may rise slowly during storage. Mixing pasteurized homogenized mil with raw milk will cause rancidity.

Mastitis is a defensive inflammatory response by dairy animals, the extent to which is variable according to the nature of the stimulus and responsiveness of the animal (Hillerton, 1996). Subclinical mastitis is a mild response either due to low stimulation and poor recognition of the irritant by the host defenses or rapid effectiveness in removing the stimulus, and is undetectable without detailed investigation. An infected udder will shed pathogens in the milk depending on the etiology of the infection and at any rate when the numbers are greater than $1 \times 10^{7}$ (Mabbit et al., 1987).

On the other hand, clinical mastitis cases present when there is severe response by the immune system that results in changes in the rheology of the secretion usually symptomized by milk clotting and colour changes.

The udder tissue appears abnormal, swollen, red in colour and painful (Hillerton 1996), and systemic effects of high temperature may result to death in severe cases. Slimy secretions arise due to leucocytes and fibrin. The animal produces a lot of polymorphonuclear cells as a defensive mechanism. Therefore, most milk samples with high SCC are related to environmental mastitis and that a subclinical part of a bacteriologically positive milk sample is associated with subclinical mastitis, and with environmental mastitis, results in an increased SCC but without clinical symptoms. 
Table.1 Mean values of FFA content (ADV $\mu \mathrm{eq} / \mathrm{ml}$ ) and descriptive characteristics for Somatic cell counts

\begin{tabular}{|c|c|c|c|c|c|c|c|}
\hline Village & $\mathbf{N}$ & Mean & Maximum & Minimum & SD & SEM & $\mathbf{C V}$ \\
\hline \multicolumn{8}{|c|}{ Free Fatty acid (ADV) $(\mu e q / m l)$} \\
\hline 1 & 15 & $0.743 *$ & 1.592 & $0.199 *$ & 0.402 & $1.04 \times 10^{-1}$ & 54 \\
\hline 2 & 18 & 3.272 & 6.567 & 1.990 & 1.093 & $2.60 \times 10^{-1}$ & 33 \\
\hline 3 & 19 & 3.31 & 4.776 & 0.597 & 1.060 & $2.40 \times 10^{-1}$ & 32 \\
\hline 4 & 10 & 4.46 & 5.373 & 2.985 & 0.752 & $2.30 \times 10^{-1}$ & 16.90 \\
\hline 5 & 10 & 3.99 & 5.174 & 3.184 & 0.672 & $2.12 \times 10^{-1}$ & 16.84 \\
\hline \multicolumn{8}{|c|}{ Somatic cell counts } \\
\hline 1 & 20 & - & - & - & - & - & - \\
\hline 2 & 20 & - & - & - & - & - & - \\
\hline 3 & 20 & $4.83 \times 10^{6}$ & $1.5 \times 10^{7}$ & $4.0 \times 10^{5}$ & $4.02 \times 10^{6}$ & $8.99 \times 10^{5}$ & 32 \\
\hline 4 & 10 & $1.70 \times 10^{6}$ & $3.7 \times 10^{6}$ & $1.7 \times 10^{5}$ & $1.0 \times 10^{6}$ & $3.16 \times 10^{5}$ & 16.90 \\
\hline 5 & 10 & $4.98 \times 10^{6}$ & $1.0 \times 10^{7}$ & $1.6 \times 10^{5}$ & $2.6 \times 10^{6}$ & $8.22 \times 10^{5}$ & 16.84 \\
\hline \multicolumn{8}{|c|}{ Milk pH } \\
\hline 1 & 20 & 6.49 & 6.59 & 6.02 & 0.047 & $1.05 \times 10^{-2}$ & 0.724 \\
\hline 2 & 18 & 6.68 & 7.21 & 6.16 & 0.245 & $5.8 \times 10^{-2}$ & 3.57 \\
\hline 3 & 20 & 6.60 & 6.68 & 6.48 & 0.062 & $1.38 \times 10^{-2}$ & 0.94 \\
\hline 4 & 10 & 6.88 & 6.99 & 6.77 & 0.067 & $2.12 \times 10^{-2}$ & 0.974 \\
\hline 5 & 10 & 6.97 & 7.10 & 6.87 & 0.0785 & $2.48 \times 10^{-2}$ & 1.13 \\
\hline
\end{tabular}

*Values obtained are far more deviant from the others and thus considered outliers.

\section{Somatic cell counts}

The mean SCC obtained was $3.8 \times 10^{6} \pm$ $92.54 \times 10^{5}$ ) cells $/ \mathrm{ml}$ of milk (Table 1 ). This is way beyond the recommended United States of America goat milk standards (Droke et al., 1993). In the United Kingdom, Hall and Rycroft (2007) reported a mean SCC in uninfected teats as $428 \times 10^{3}$ cells $/ \mathrm{ml}$ of milk with the uninfected goats having $<1.0 \times 10^{6}$ cells $/ \mathrm{ml}$, while those infected teats were $2.785 \times 10^{6} \mathrm{cell} / \mathrm{ml}$. Higher SCC have also been observed for goat milk samples and were found to exceed that of cows (Droke et al., 1993). The current US standard for goat milk is set at $1.0 \times 10^{6}$ cells $/ \mathrm{ml}$. In Kenya, Ndegwa et al., (2000) reported a subclinical mastitis prevalence using three measures, which was $9.8 \%$ by CMT, $9.7 \%$ by direct leukocyte counts and $28.7 \%$ by bacterial isolation. However, White and Hinckely (1999) and
Gelasakis et al., (2016) have reported a prevalence rate of $31.7 \%$ to $36.4 \%(n=1061)$. Bacterial organisms were isolated in 127 cases (22.5\%) of CMT-negative samples. This shows that the presence of bacteria does not lead to host reaction to produce reactions to indicate the disease and therefore does not warrant treatment. This agrees with Chen $e t$ al., (2010) who found that higher SCC in milk does not lead to high positive cases of presence of bacteria in milk. Park and Humphrey (1986) and Bergonier et al., (2003) have recommended SCC as an acceptable index for mastitis, and this has for many years been used as an index for bovine mastitis. In the same study, they noted that many farmers observe high SCC in goat milk. The SCC in milk from normal uninfected goats is much higher than in cows especially in late lactation. Polymorphonuclear cells are the main cells in milk from uninfected mammary 
glands and their enumeration is a reliable indicator for the presence or absence of udder lesions. The SCC is preferred (Persson and Olofsson 2011) to bacteriological tests as a criterion for detecting inflammation of the udder tissue. The SCC in mil is of particular interest in the diagnosis of subclinical forms of mastitis since it cannot be recognizes by redness, udder tenderness or by macroscopic changes in the milk.

\section{Sensory evaluation}

The sensory evaluation of the milk samples was done by the ten taters and the mean values on the Hedonic scale varied between $2.91 \pm 0.85$ (SEM 0.26) and 2.93 \pm 0.68 (SEM 0.22), where most of the tasters scored a characteristic of slightly liking the milk and this was not significant. This means that the sensory characteristic was slightly liked. Chen et al., (2010) did not find any change in the sensory characteristics in cheese made from milk with high SCC. However, cheese made from milk with high SCC did not affect the yield of semisoft cheese but produced inferior sensory quality of aged cheeses but not affect the composition.

Mastitis can result to an altered chemical composition of the milk that affects milk and dairy products quality. Tucker and Woods (1991) reported milk enzyme assays can be used for mastitis screening, especially using catalase and $\mathrm{N}$-acetyl- $\beta$-D-glucouronidase, and that mastitis leads to an elevated enzyme activity in milk, making the enzymes more significant. The enzyme N-acetyl glucosamidase (EC 3.2.130) has also been used in the diagnostic tests for udder infections that become more permeable and increase levels of proteins and blood originating enzymes in milk. In severe infections, lipases and proteinases levels can be very high leading to the development of off-flavour or causing milk instability, and this agrees with Chen et al., (2010) on cheese made from milk with high SCC. Ma et al., (2000) also report similar findings that high SCC milk, had sensory defects of rancidity and bitterness, resulting in low overall quality ratings and were consistent with higher levels of lipolysis and proteolysis. Hence, mastitis adversely affected the quality of pasteurized fluid milk. Lipases are responsible for the formation of off-flavour while proteinases cause physical changes like gelation. Tucker and Woods (1991) found plasmin enzyme, which is of significance in mastitis infection, in normal milk. This plasmin is heat stable and cleaves into peptide chains of casein substrate molecules after lysine residues and to a lesser extent arginine, to produce peptides mostly in the proteose-peptone fraction of the milk plasmin exists in an active form as plasminogen, which on transfer to milk is activated to the active plasmin, probably by the micro-plasminogen activator enzymes. The above may explain and agree with the bad flavor of milk found in the current study where tasters had a "slight dislike".

\section{Effects on milk composition and $\mathbf{p H}$}

Mastitis condition increases the permeability of the membrane and the level of soluble nitrogen as well as the non-protein (NPN) levels as reported by Leitner et al., (2004) due to subclinical mastitis infection. The changes include low lactose, high whey protein and albumin concentration, high plasmin activity, low curd yield and an increase in proteasepeptone activity of up to 1.5 times the normal rate.

The acid degree value (ADV) and $\mathrm{pH}$ Pearson's correlation of ADV and $\mathrm{pH}$ descriptive statistics showed inverse relationships. In village 3, 4 and 5, the ADV and $\mathrm{pH}$ were: (+341and -0.3241); (-0.2058, $+0.1273)$ and $(+0.701,-0.0814)$, respectively. The mean $\mathrm{pH}$ obtained was $6.72 \pm 0.1$. This is 
far above the $\mathrm{pH}$ of 6.48, which is the standard recommended by the US FDA/CFSAN (2003). Goat milk pH tends to greatly determine the extent of heat treatment. In a study by Montilla and Calvo (1997) on heat stability of goat milk at different $\mathrm{pH}$ values, they found out that goat's milk stability is lower than that of cow's milk. They further noticed that samples at $\mathrm{pH} 6.7$ heated at $140^{\circ} \mathrm{Cand}$ samples at $\mathrm{pH} 6.9$ or higher heated at $145^{\circ} \mathrm{Cusing}$ the direct ultraheat treatment (UHT) method, the milk coagulated. Elsewhere, in a study by Gall (1981) it was noted that the acidity of goat milk at $\mathrm{pH} 6.4$ is slightly lower than that of the cow which was at $\mathrm{pH} 6.7$.

From the study, it is concluded that the levels of free fatty acids and SCC were higher than the recommended levels which impart bad flavors in the milk and may be rejected by consumers.

\section{Acknowledgement}

The author acknowledges the Community Dairy Goat Programme of Egerton University and appreciates the acceptance and kind participation of the farmers.

\section{References}

Barlow, J. 2011. Mastitis therapy and antimicrobial susceptibility: a multispecies review with a focus on antibiotic treatment of mastitis in dairy cattle. J Mammary Gland Biol Neoplasia. 2011 Dec; 16(4): 383-407. doi: 10.1007/s 10911-011-9235-z.

Bergonier, D., de Crémoux, R., Rupp R, Lagriffoul, G., Berthelot, X. 2003. Mastitis of dairy small ruminants. Veterinary Resources. 2003 Sep-Oct; 34(5): 689-716.

Central Bureau of Statistics (CBS). 2002. Statistical abstract. Ministry of Planning and National Development, Nairobi. Kenya.

Chen, S.X., Wang, J.Z., Van Kessel, J.S., Ren, F.Z., Zeng, S.S. 2010. Effect of somatic cell count in goat milk on yield, sensory quality, and fatty acid profile of semisoft cheese. Journal of Dairy Science Apr; 93(4): 1345-54. doi: 10.3168/jds.2009-2366.

Corks, L.V. and Van Rede, C. 1966. Laboratory Handbook for oil and fat analysis. Academic Press, London, p113-117.

Coulon, J.B., Gasqui, P., Barmounin, J., Ollier, A., Pradel, P., Pomies, D. 2002. Effects of mastitis and related germ on milk yield and composition during naturally occurring udder infections in dairy cows. Animal Research, 51:383-393.

DPC. 1991. Guidelines for preventing offflavors in milk. http://www. dairypc.org/

Droke, E.A., Paape, M.J. and Di Carlo, A.L. 1993. Prevalence of high somatic cell counts in bulk tank goat milk. Journal of dairy $\quad$ Science, 76:1035-1039. http://jds.fass.org/cgi/content/full/76/4/1 035

Gall, C., 1981. Milk production in goat production, Ed Gall C. Academic Press, London, p309-340.

Gelasakis, A.I., Angelidis, A.S., Giannakou, R., Filioussis, G., Kalamaki, M.S., Arsenos, G. 2016. Bacterial subclinical mastitis and its effect on milk yield in low-input dairy goat herds. Journal of Dairy Science. 2016 May; 99(5):36983708. doi: 10.3168/jds.2015-10694.

Hall, S.M. and Rycroft, A.N. 2007. Causative organisms and somatic cell counts in subclinical Intramammary infections in the UK. Journal of Dairy Science 160(1):19-20. http://www.ncbi.nlm. nih.gov/entrez/query.fcgi

Hillerton, J.E. 1996. Control of mastitis. Chapter 9 in progress in dairy science, Phillips, CJ (Ed). Institute of Animal 
Health. Pp. 171-174.

James Ombiro Ondiek, Ogore, P.B., Shakala, E.K. and Kaburu, G.M. 2013. Prevalence of bovine mastitis, its therapeutics and control in Tatton Agriculture Park, Egerton University, Njoro District of Kenya. Basic Research Journal of Agricultural Science and Review. 2(1): 15-20 January 2013. http//www.basicresearchjournals.org

Koop, G., Nielen, M., van Werven, T. 2012. Diagnostic tools to monitor udder health in dairy goats. The Veterinarian Quarterly. 2012; 32(1):37-44. doi: 10.1080/01652176.2012.675634.

Leitner, G., Merin, U. and Silakove, N. 2004. Changes in milk composition affected by subclinical mastitis in goats. Journal of dairy Science, 87:1719-1726. In http://jds.fass.org/cgi/content/full/87/6/1 719

Li, N., Richoux, R., Boutinaud, M., Martin, P., Gagnaire, V. 2014. Role of somatic cells on dairy processes and products: a review. Dairy Sci Technol. 2014; 94(6):517-538.

Ma, Y., Ryan, C., Barbano, D.M., Galton, D.M., Rudan, M.A., and Boor, K.J. 2000. Effects of somatic cell count on quality and shelf-life of pasteurized fluid milk. Journal of Dairy Science Feb; 83(2): 264-74.

Mabbit, L.A., Davis, F.L., Law, B.A. and Marshall, V.M. 1987. Microbiology of milk and milk products. Chap 5 in Essays Agricultural and Food Microbiology, JR Norris and GL Pettipher (Eds.), John Willey and Sons, New York, Pp. 135-136.

Montilla, A. and Calvo, M.M. 1997. Goat milk stability during heat treatment effects on $\mathrm{pH}$ and phosphates. Journal of Agriculture and Food Chemistry, 45: (3), 931-934.

Murphy, M., Buckley, J.F., Whyte, P., O'Mahony, M., Anderson, W., Wall,
P.G., Fanning, S. 2007. Surveillance of dairy production holdings supplying raw milk to the farmhouse cheese sector for Escherichia coli O157, O26 and O111. Zoonoses Public Health. 2007; 54(9-10): 358-65.

Nancy, M.C., Bleumink-Pluym, Froukje, V., Wim, G., Bernard, A.M. van der Zeijst, Ben, N.F. 1999. A novel approach for the construction of a Campylobacter mutant library. Microbiology 145: 2145-2151, doi: 10.1099/13500872145-8-2145

Ndegwa, E.N., Mulei, C.M., Munyua, S.J. 2000. The prevalence of subclinical mastitis in dairy goats in Kenya. Journal of South African Veterinary Association. Mar; 71(1):25-27.

Oliver, S.P., Boor, K.J., Murphy, S.C., Murinda, S.E. 2009. Food safety hazards associated with consumption of raw milk. Foodborne Pathological Diseases. 6(7): 793-806. doi: 10.1089/fpd.2009.0302.

Omore, A.O. 1997. Epidemiology and Economics of Mastitis in Smallholder dairy sector in Kiambu District, Kenya. $\mathrm{PhD}$ Thesis, University of Nairobi.

Omore, A.O., McDermott, J.J., Arimi, S.M., Kyule, M.N. and Ouma, D. 1996. A longitudinal study of milk SCC and bacterial culture from cows on Smallholder dairy farms in Kiambu District, Kenya. A rapid Appraisal -SDP Report. MALDM/KARI/ILRI/DFID Project.

Omore, A.O., Muriuki, H., Kenyanjui, M., Owango, M. and Staal, S. 1999. The Kenya Dairy Subsector. A rapid Appraisal $\quad$ SDP Report. MALDM/KARI/ILRI/DFID Project.

Ondiek, J.O., Abdulrazak, S.A., Tuitoek, J.K. and Bareeba, F.B. 1999. The effects of Gliricidia sepium and maize bran as supplementary feed to Rhodes grass hay on intake, digestion and live-weight of 
dairy goats. Livestock Production Science, 61:27-38.

Ondiek, J.O., Tuitoek, J.K., Abdulrazak, S.A., Bareeba, F.B. and Fujihara, T. 2000. Use of Leucaena leucocephala and Gliricidia sepium as nitrogen sources in supplementary concentrates for dairy goats offered Rhodes grass hay. AsianAustralasian Journal of Animal Science 13:1249-1254.

Park, W.Y. and Humphrey, R.D. 1986. Bacterial cell counts in goat milk and their correlation with somatic cell counts, percent fat and protein. Journal of Dairy Science, 69(10): 3327.

Persson, Y., and Olofsson, I. 2011. Direct and indirect measurement of somatic cell count as indicator of intramammary infection in dairy goats. Acta Veterinaria Scandinavica 2011 Mar 4; 53:15. doi: 10.1186/1751-0147-53-15.

Schalm, O.W., Carroll, E.J. and Jain, N.C. 1971. Bovine mastitis. Lea and Febiger, Philadelphia, PA.

Shitandi, A., and Gathoni, K. 2004. Assessment of California Mastitis Test usage in smallholder dairy herds and risks of violative antimicrobial residues. Journal of Veterinary Science, 5(1):5-9.

Shitandi, A., and Sternesjo, A. 2001. Detection of antimicrobial drugs residues in Kenyan milk. Journal of Food
Protection, 21:205-214.

Shitandi, A., Gathoni, A., Galgalo, T. and Mwangi, M. 2004. Prevalence of bovine mastitis among smallholder dairy herd in Kenya. Israel Journal of Veterinary Medicine, 9:1-2.

Silva, J.B., Fagundes, G.M., Soares, J.P., Fonseca, A.H., Muir, J.P. 2014. A comparative study of production performance and animal health practices in organic and conventional dairy systems. Tropical Animal Health Production. 46(7):1287-95. doi: 10.1007/s11250-014-0642-1.

Tucker, G.A. and Woods, L.F.J. 1991. Enzymes in food processing. Blackie and Sons Ltd, London. P. 103-108.

US FDA/CFSAN. 2003. Approximate $\mathrm{pH}$ for foods and food products. In http://www.cfsan.fda.gov/list.html

US FDA/CSFAN. 2005. Direct microscopic Somatic Cell Counts: Milk safety References, National Conference on Interstate Milk shipment. http://www.csfan.fda.gov/ ear/mi_05_3 7.html

White, E.C. and Hinckley, L.S. 1999. Prevalence of mastitis pathogens in goat milk. Small Ruminant Research, Vol. $33: 117-121$. DOI - 10.1016/S09214488(99)00013-9.

\section{How to cite this article:}

Ondiek, J.O., P.B. Ogore and Kemboi, F. 2018. Clinical Mastitis Gives Off-Flavor and Reduces Quality of Milk in Smallholder Goat Farms. Int.J.Curr.Microbiol.App.Sci. 7(01): 2387-2396. doi: https://doi.org/10.20546/ijcmas.2018.701.287 